\title{
Temporal and Spatial Variation in, and Population Exposure to, Summertime Ground-Level Ozone in Beijing
}

\author{
Hui Zhao ${ }^{1}$ (D), Youfei Zheng ${ }^{1,2, *}$, Ting $\mathrm{Li}^{2}{ }^{2} \mathrm{Li}_{\text {Wei }}{ }^{2}$ and Qing Guan ${ }^{2}$ \\ 1 Key Laboratory for Aerosol-Cloud-Precipitation of China Meteorological Administration, \\ Nanjing University of Information Science and Technology, Nanjing 210044, China; zhaohui_nuist@163.com \\ 2 Key Laboratory of Atmospheric Environment Monitoring and Pollution Control, Collaborative Innovation \\ Center of Atmospheric Environment and Equipment Technology, Nanjing University of Information Science \\ and Technology, Nanjing 210044, China; c2015liting@163.com (T.L.); 20161244361@nuist.edu.cn (L.W.); \\ 20161219415@nuist.edu.cn (Q.G.) \\ * Correspondence: zhengyf@nuist.edu.cn
}

Received: 7 February 2018; Accepted: 26 March 2018; Published: 29 March 2018

\begin{abstract}
Ground-level ozone pollution in Beijing has been causing concern among the public due to the risks posed to human health. This study analyzed the temporal and spatial distribution of, and investigated population exposure to, ground-level ozone. We analyzed hourly ground-level ozone data from 35 ambient air quality monitoring sites, including urban, suburban, background, and traffic monitoring sites, during the summer in Beijing from 2014 to 2017. The results showed that the four-year mean ozone concentrations for urban, suburban, background, and traffic monitoring sites were $95.1,99.8,95.9$, and $74.2 \mu \mathrm{g} / \mathrm{m}^{3}$, respectively. A total of $44,43,45$, and 43 days exceeded the Chinese National Ambient Air Quality Standards (NAAQS) threshold for ground-level ozone in 2014, 2015, 2016, and 2017, respectively. The mean ozone concentration was higher in suburban sites than in urban sites, and the traffic monitoring sites had the lowest concentration. The diurnal variation in ground-level ozone concentration at the four types of monitoring sites displayed a single-peak curve. The peak and valley values occurred at 3:00-4:00 p.m. and 7:00 a.m., respectively. Spatially, ground-level ozone concentrations decreased in gradient from the north to the south. Population exposure levels were calculated based on ground-level ozone concentrations and population data. Approximately $50.38 \%, 44.85 \%$, and $48.49 \%$ of the total population of Beijing were exposed to ground-level ozone concentrations exceeding the Chinese NAAQS threshold in 2014, 2015, and 2016, respectively.
\end{abstract}

Keywords: ground-level ozone; atmospheric oxidation; exposure; China

\section{Introduction}

Stratospheric ozone can protect the Earth's surface from dangerous ultraviolet radiation from the sun, but ground-level ozone $\left(\mathrm{O}_{3}\right)$ is an important atmospheric pollutant and agent of climate change [1]. Ground-level ozone is mainly produced by a complex photochemical reaction between nitrogen oxides $\left(\mathrm{NO}_{\mathrm{X}}=\mathrm{NO}+\mathrm{NO}_{2}\right)$ and volatile organic compounds (VOCs) under strong solar radiation. Ozone, the third most important greenhouse gas in terms of radiative forcing [2], is an important factor affecting air quality. The measured ozone concentrations are due to the combination of the hemispheric background level, intercontinental transport, stratospheric intrusion, and local and regional ozone production [3-7]. High ground-level ozone concentration has attracted worldwide attention from both the scientific and regulatory communities due to its adverse impacts on air quality, human health, 
crops, forests, materials, and climate change [8-19]. As valuable tools for ozone risk and exposure assessment, the generation of optimal ozone maps is challenging [6].

To study the spatial and temporal characteristics of ground-level ozone, a large number of long-term monitoring sites have been established worldwide, especially in the United States and Europe. For instance, Vingarzan et al. [20] reported rising ozone background levels over the midlatitudes of the Northern hemisphere at rates ranging from approximately 0.5 to $2 \%$ per year. Derwent et al. [21] reported that the trend in annual baseline ozone increase, over a 20-year period from 1987 to 2007, was $0.31 \pm 0.12 \mathrm{ppb}$ per year at the atmospheric research station in Mace Head, Ireland. Jaffe et al. [22] showed that $\mathrm{O}_{3}$ increased significantly, with a mean trend of $0.26 \mathrm{ppbv}$ per year at seven out of nine sites in the Western US. Ozone precursor emission and solar radiation in the Mediterranean are usually high, especially during the summer months. A trend analysis of the European ozone monitoring site data from 1993 to 2005 showed that some Mediterranean cities recorded one-hour mean ozone concentrations exceeding $300 \mu \mathrm{g} / \mathrm{m}^{3}$ [23,24]. Lelieveld et al. [25] reported that summer ozone concentrations were 2.5-3 times higher in the Mediterranean area than in the background troposphere.

Given rapid economic growth and accelerated urbanization, China has been facing a complex regional air pollution challenge, characterized by high concentrations of particulate matter with an aerodynamic diameter smaller than $2.5 \mu \mathrm{m}\left(\mathrm{PM}_{2.5}\right)$ and $\mathrm{O}_{3}$, especially in economically developed regions, such as Beijing-Tianjin-Hebei, the Yangtze River Delta, and the Pearl River Delta [26]. To control air pollution in China, the Chinese government introduced the Air Pollution Prevention and Control Action Plan (the "Action Plan") in 2013. According to a study of the effects of the Action Plan's implementation [27], the mean concentrations of $\mathrm{PM}_{2.5}$, particulate matter $\left(\mathrm{PM}_{10}\right)$, sulfur dioxide $\left(\mathrm{SO}_{2}\right)$, and oxides of nitrogen $\left(\mathrm{NO}_{\mathrm{X}}\right)$ showed a downward trend from 2013 to 2017. However, a reduction in $\mathrm{PM}_{2.5}$ and $\mathrm{O}_{3}$ precursors could actually lead to an increase in ground-level ozone concentration [28]. Some studies have reported that ground-level ozone has overtaken $\mathrm{PM}_{2.5}$ as the main summertime air pollutant in 74 Chinese cities [29]. Thus, ground-level ozone pollution in China has become a hot research topic in the atmospheric environment field and requires further research.

Meteorological factors and ozone precursors are also closely related to one another; all factors influence the concentration of ground-level ozone in the ambient air [30-32]. Xing et al. [5] showed that ozone precursors significantly increased in China ( $\mathrm{NO}_{\mathrm{X}}:+4.3 \%$ /year; VOCs: $+2.3 \%$ /year) between 1990 and 2010. Lin et al. [33] found that the probability of ozone air quality standard exceedances was strongly correlated with temperature, suggesting that an increase in temperature would aggravate ozone pollution. Zhang et al. [34] reported that summertime ground-level ozone concentrations increased during periods of high temperatures in the Northeastern United States. Tarasova et al. [35] suggested that $70 \%$ of the day-to-day ozone variability could be explained by meteorological condition changes in temperature, relative humidity, and wind speed. Wind speed and direction were also found to affect the long-range transport of ground-level ozone and the movement of its precursors from polluted areas [36].

Human health is also affected by exposure to ground-level ozone. A large number of epidemiological studies have found an association between ambient ozone levels and premature mortality. For the protection of human health, the ozone concentration standards for daily maximum 8-h and 1-h ozone concentrations set by the World Health Organization (WHO) [37] are based on associations between daily mortality rates and ozone concentrations. For class 1 (remote) areas, the National Ambient Air Quality Standards (NAAQS) of China (GB 3095-2012) established daily maximum values of $100 \mu \mathrm{g} / \mathrm{m}^{3}$ and $160 \mu \mathrm{g} / \mathrm{m}^{3}$ for 8-h and 1-h ozone concentrations, respectively. For class 2 (urban/industrial and surrounding rural) areas, these values are 160 and $200 \mu \mathrm{g} / \mathrm{m}^{3}$, respectively [38]. Although numerous studies have focused on health impact assessments of ground-level ozone pollution [39-41], these are less common in China.

Beijing has long suffered from serious ground-level ozone pollution, especially in summer [42-44]. Several studies on ground-level ozone have been completed in Beijing, and these studies have mostly focused on temporal and spatial variations, regional transport, production processes, and formation 
regimes. For example, Tang et al. [45] found that ground-level ozone concentrations in Beijing increased at a rate of $1.1 \pm 0.5 \mathrm{ppbv} /$ year from 2001 to 2006. Wang et al. [46] demonstrated that regional pollution sources contributed more than $34-88 \%$ to the peak ground-level ozone level at an urban site in Beijing, with an average contribution of $62 \%$. Tang et al. [47] concluded that high amounts of ground-level ozone are strongly stimulated by non-methane volatile organic compounds (NMVOC) emissions, but the $\mathrm{NO}_{\mathrm{X}}$ emissions strongly inhibit ground-level ozone formation. Notably, stringent air pollution control measures implemented by the local government during various international events have been conducive to the reduction of pollutants, except for ground-level ozone [48]. However, due to the lack of sufficient observational data, ground-level ozone concentration data from a few monitoring stations or model simulations have been used by these previous studies, considerably reducing the reliability of the results. Therefore, studying ground-level ozone pollution in Beijing using spatial interpolation using a large amount of ground-level ozone observation data that covers the entire study area is an accurate and reliable method.

In this study, hourly ground-level ozone concentration data were continuously collected at 35 sites in Beijing over the summer. The main goals of this study were to determine the temporal and spatial characteristics of ground-level ozone concentration during the summers in Beijing from 2014 to 2017 and to estimate the risk to the total population of Beijing from ground-level ozone in summer.

\section{Methods}

\subsection{Study Area}

Beijing $\left(40^{\circ} \mathrm{N}, 116^{\circ} \mathrm{E}\right)$, the capital city of China, is located in Northern China, with 16 administrative subdivisions including six urban districts (Dongcheng, Xicheng, Zhaoyang, Fengtai, Haidian, and Shijingshan) and 10 suburban districts (Changping, Daxing, Mentougou, Tongzhou, Fangshan, Shunyi, Pinggu, Huairou, Minyun, and Yanqing). The city has a population of over 20 million and covers an area of $16,800 \mathrm{~km}^{2}$. Beijing has undergone rapid economic growth since the 1980s, accompanied by sustained growth in energy consumption. However, economic development has created a series of atmospheric pollution problems with especially severe ground-level ozone pollution in the summer.

\subsection{Data}

The Beijing Municipal Environmental Protection Bureau publishes real time monitoring concentration data for six major air pollutants on a web platform (http:/ / zx.bjmemc.com.cn/), offering a unique resource for researchers to study the characteristics of air quality and air pollutants in Beijing. In this paper, ground-level ozone concentration data from 35 air quality monitoring sites in Beijing were recorded by the web platform. All the sites are listed in Table 1, and the locations are described in Figure 1. The sites were classified into four types according to the monitoring function [49]: 12 urban sites, 11 suburban sites, 5 traffic monitoring sites, and 7 background sites. We used the hourly ground-level ozone concentration data for the summer months, which include June, July, and August from 2014 to 2017.

Hourly meteorological data, including air temperature $(T)$, relative humidity $(R H)$, precipitation $(P)$ and wind speed $(W D)$, were collected from the China Meteorological Data Sharing Service System Administration (http:// data.cma.cn/site/index.html). We obtained hourly meteorological data only for 2016 and 2017.

In addition, the population data from Beijing's 16 districts were obtained by the Beijing statistical yearbook for every year from 2015 to 2017, as shown in Table 2. 


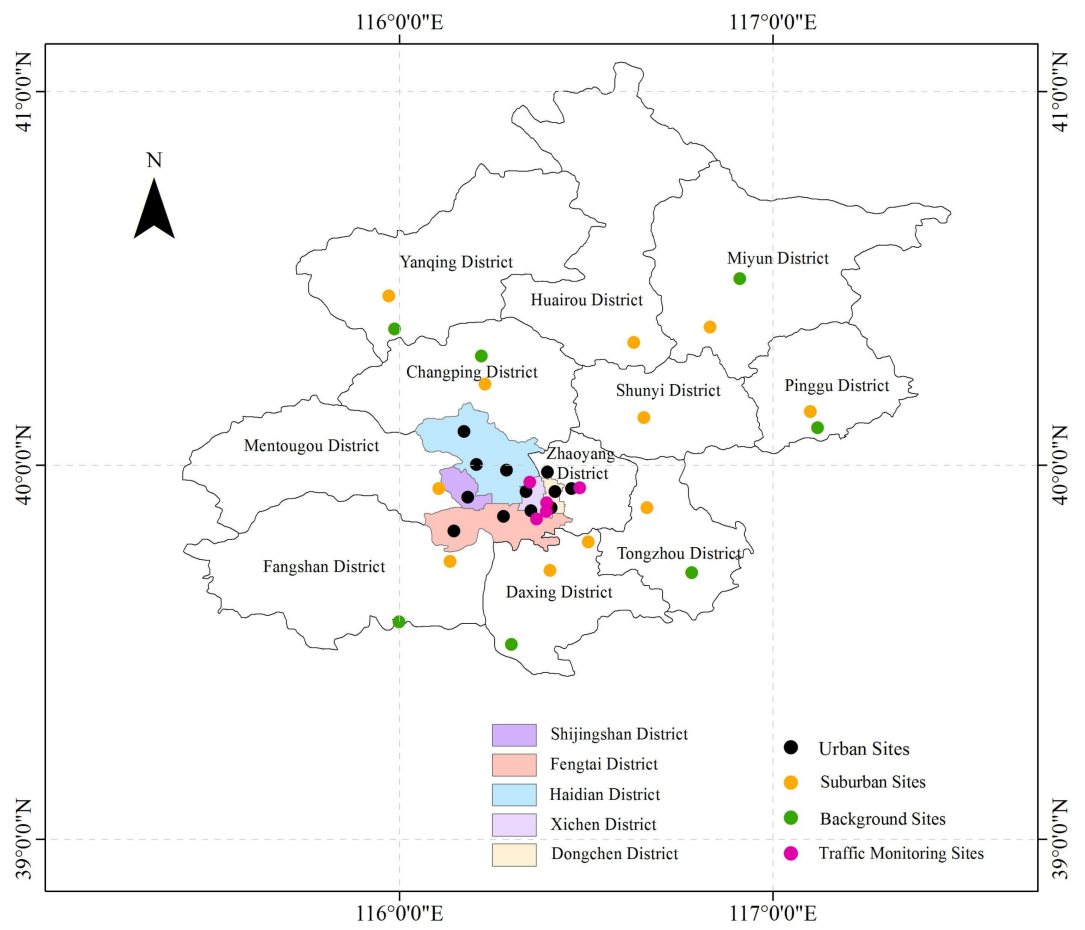

Figure 1. Locations of 35 ambient air quality monitoring sites in Beijing.

Table 1. Types and locations of air quality monitoring sites in Beijing.

\begin{tabular}{|c|c|c|}
\hline Site ID & Type & Location \\
\hline Dongsi & & $116.42^{\circ} \mathrm{E}, 39.93^{\circ} \mathrm{N}$ \\
\hline Temple of Heaven & & $116.41^{\circ} \mathrm{E}, 39.89^{\circ} \mathrm{N}$ \\
\hline West Park Officials & & $116.34^{\circ} \mathrm{E}, 39.93^{\circ} \mathrm{N}$ \\
\hline West Wanshou Nishinomiya & & $116.35^{\circ} \mathrm{E}, 39.88^{\circ} \mathrm{N}$ \\
\hline Olympic Sports Center & & $116.40^{\circ} \mathrm{E}, 39.98^{\circ} \mathrm{N}$ \\
\hline Agricultural Exhibition Hall & & $116.46^{\circ} \mathrm{E}, 39.94^{\circ} \mathrm{N}$ \\
\hline Wanliu & Urban Sites & $116.29^{\circ} \mathrm{E}, 39.99^{\circ} \mathrm{N}$ \\
\hline Northern New Area & & $116.17^{\circ} \mathrm{E}, 40.09^{\circ} \mathrm{N}$ \\
\hline Botanical Garden & & $116.21^{\circ} \mathrm{E}, 40.00^{\circ} \mathrm{N}$ \\
\hline Fengtai garden & & $116.28^{\circ} \mathrm{E}, 39.86^{\circ} \mathrm{N}$ \\
\hline Yungang & & $116.15^{\circ} \mathrm{E}, 39.82^{\circ} \mathrm{N}$ \\
\hline Shijingshan city & & $116.18^{\circ} \mathrm{E}, 39.91^{\circ} \mathrm{N}$ \\
\hline Liangxiang & & $116.14^{\circ} \mathrm{E}, 39.74^{\circ} \mathrm{N}$ \\
\hline Daxing & & $116.40^{\circ} \mathrm{E}, 39.72^{\circ} \mathrm{N}$ \\
\hline Yizhuang & & $116.51^{\circ} \mathrm{E}, 39.80^{\circ} \mathrm{N}$ \\
\hline Tongzhou & & $116.66^{\circ} \mathrm{E}, 39.89^{\circ} \mathrm{N}$ \\
\hline Shunyi & & $116.66^{\circ} \mathrm{E}, 40.13^{\circ} \mathrm{N}$ \\
\hline Changping & Suburban Sites & $116.23^{\circ} \mathrm{E}, 40.22^{\circ} \mathrm{N}$ \\
\hline Mentougou & & $116.11^{\circ} \mathrm{E}, 39.94^{\circ} \mathrm{N}$ \\
\hline Pinggu & & $117.10^{\circ} \mathrm{E}, 40.14^{\circ} \mathrm{N}$ \\
\hline Huairou & & $116.63^{\circ} \mathrm{E}, 40.33^{\circ} \mathrm{N}$ \\
\hline Miyun & & $116.83^{\circ} \mathrm{E}, 40.37^{\circ} \mathrm{N}$ \\
\hline Yanqing & & $115.97^{\circ} \mathrm{E}, 40.45^{\circ} \mathrm{N}$ \\
\hline
\end{tabular}


Table 1. Cont.

\begin{tabular}{|c|c|c|}
\hline Site ID & Type & Location \\
\hline Dingling & & $116.22^{\circ} \mathrm{E}, 40.29^{\circ} \mathrm{N}$ \\
\hline Badaling & & $115.99^{\circ} \mathrm{E}, 40.37^{\circ} \mathrm{N}$ \\
\hline Miyun Reservoir & & $116.91^{\circ} \mathrm{E}, 40.50^{\circ} \mathrm{N}$ \\
\hline Donggaocun & Background Sites & $117.12^{\circ} \mathrm{E}, 40.10^{\circ} \mathrm{N}$ \\
\hline Yongledian & & $116.78^{\circ} \mathrm{E}, 39.71^{\circ} \mathrm{N}$ \\
\hline Yufa & & $116.30^{\circ} \mathrm{E}, 39.52^{\circ} \mathrm{N}$ \\
\hline Liulihe & & $116.00^{\circ} \mathrm{E}, 39.58^{\circ} \mathrm{N}$ \\
\hline Qianmen East Street & & $116.40^{\circ} \mathrm{E}, 39.90^{\circ} \mathrm{N}$ \\
\hline Yongdingmen Inner Street & & $116.39^{\circ} \mathrm{E}, 39.88^{\circ} \mathrm{N}$ \\
\hline Xizhimen North Street & Traffic Monitoring Sites & $116.35^{\circ} \mathrm{E}, 39.95^{\circ} \mathrm{N}$ \\
\hline South 3rd Ring Road & & $116.37^{\circ} \mathrm{E}, 39.86^{\circ} \mathrm{N}$ \\
\hline East 4th Ring Road & & $116.48^{\circ} \mathrm{E}, 39.94^{\circ} \mathrm{N}$ \\
\hline
\end{tabular}

Table 2. The population for Beijing's 16 districts from 2014 to 2016.

\begin{tabular}{cccc}
\hline District & $\begin{array}{c}\text { 2014 Population } \\
\text { (Thousands) }\end{array}$ & $\begin{array}{c}\text { 2015 Population } \\
\text { (Thousands) }\end{array}$ & $\begin{array}{c}\text { 2016 Population } \\
\text { (Thousands) }\end{array}$ \\
\hline Fengtai & 2300 & 2324 & 2255 \\
Fangshan & 1036 & 1046 & 1096 \\
Tongzhou & 1356 & 1378 & 1428 \\
Dongchen & 911 & 905 & 878 \\
Zhaoyang & 3922 & 3955 & 3856 \\
Haidian & 3678 & 3694 & 3593 \\
Daxing & 1545 & 1562 & 1694 \\
Xichen & 1302 & 1288 & 1259 \\
Yanqing & 316 & 314 & 327 \\
Shijingshan & 650 & 652 & 634 \\
Mentougou & 306 & 308 & 311 \\
Shunyi & 1004 & 1020 & 1075 \\
Pinggu & 423 & 423 & 437 \\
Huairou & 381 & 384 & 393 \\
Changping & 1908 & 1963 & 2010 \\
Miyun & 478 & 479 & 483 \\
\hline
\end{tabular}

\subsection{Statistical Models}

As a traditional statistical model, the multiple linear regression model is used to study the association between two or more independent variables and a single continuous dependent variable. The overall model can be written as:

$$
\mathrm{Y}=\mathrm{C}_{0}+\mathrm{C}_{1} \mathrm{X}_{1}+\mathrm{C}_{2} \mathrm{X}_{2}+\ldots \mathrm{C}_{\mathrm{n}} \mathrm{X}_{\mathrm{n}}
$$

where $Y$ is the dependent variable, $X_{1}, \ldots, X_{n}$ are the independent variables, and $C_{1}, \ldots, C_{n}$ are the estimated regression coefficients. In our study, $Y$ was the ozone concentration, and $C_{1}, \ldots, C_{n}$ were the meteorological factors (air temperature, relative humidity, and wind speed).

\subsection{Analysis}

For temporal analysis, the daily mean concentration for all of Beijing city was calculated by averaging concentrations reported by all 35 sites. Diurnal variations in ground-level ozone concentration for the four types of sites were determined by averaging the concentrations at various time points. The Chinese ground-level ozone standards (NAAQS-2012) state that the daily maximum 8-h and 1-h ozone concentrations for class 1 (remote) areas are $100 \mu \mathrm{g} / \mathrm{m}^{3}$ and $160 \mu \mathrm{g} / \mathrm{m}^{3}$, respectively, 
whereas for class 2 (urban/industrial and surrounding rural) areas, these values are 160 and $200 \mu \mathrm{g} / \mathrm{m}^{3}$, respectively.

According to the administrative divisions of Beijing, Beijing city is divided into five regions, including the center (Dongchen, Xichen, Zhaoyang, Haidian, Fengtai, and Shijingshan Districts), northwest (Yanqing and Changping Districts), northeast (Huairou, Miyun, Shunyi, and Pinggu Districts), southwest (Mentougou and Fangshan Districts), and southeast (Tongzhou and Daxing Districts). We calculated the annual mean concentrations of ground-level ozone in each region, based on the location of each air monitoring site.

The Inverse Distance Weighted (IDW) interpolate method was used to characterize spatial distribution, based on concentration data from the 35 monitoring sites. Many papers have studied the spatial distribution of air pollutants using this method [50-53]. We produced IDW-based interpolation maps of ground-level ozone concentration by randomly using $70 \%$ of the points, and the maps were validated with the remaining 30\%. The Root Mean Square Error (RMSE) of each ground-level ozone concentration map was calculated to determine the accuracy of the interpolation maps using the Geostatistical Analyst Extension of ArcGIS ArcMap 10.0 (ESRI, Redlands, CA, USA).

\section{Results}

\subsection{Variation in Ground-Level Ozone Concentration in Beijing}

Figure 2 shows the daily mean ozone concentration and the daily maximum 1-h and 8-h ozone concentrations. The daily mean ozone concentration in 2014 ranged from 35.8 to $157.6 \mu \mathrm{g} / \mathrm{m}^{3}$, with a mean of $94.6 \mu \mathrm{g} / \mathrm{m}^{3}$. From 2014 to 2016, annual mean concentrations slightly declined with fluctuations, with $91.3 \mu \mathrm{g} / \mathrm{m}^{3}$ being the lowest in 2016, and the daily concentration ranged from 29.4 to $149.2 \mu \mathrm{g} / \mathrm{m}^{3}$. In 2017 , the daily mean ozone concentration ranged from 30.3 to $173.4 \mu \mathrm{g} / \mathrm{m}^{3}$, with a mean of $95.6 \mu \mathrm{g} / \mathrm{m}^{3}$, which was the highest of the four years. In addition, 44, 43, 45 and 43 days exceeded the current NAAQS threshold for ground-level ozone in 2014, 2015, 2016, and 2017 , respectively.

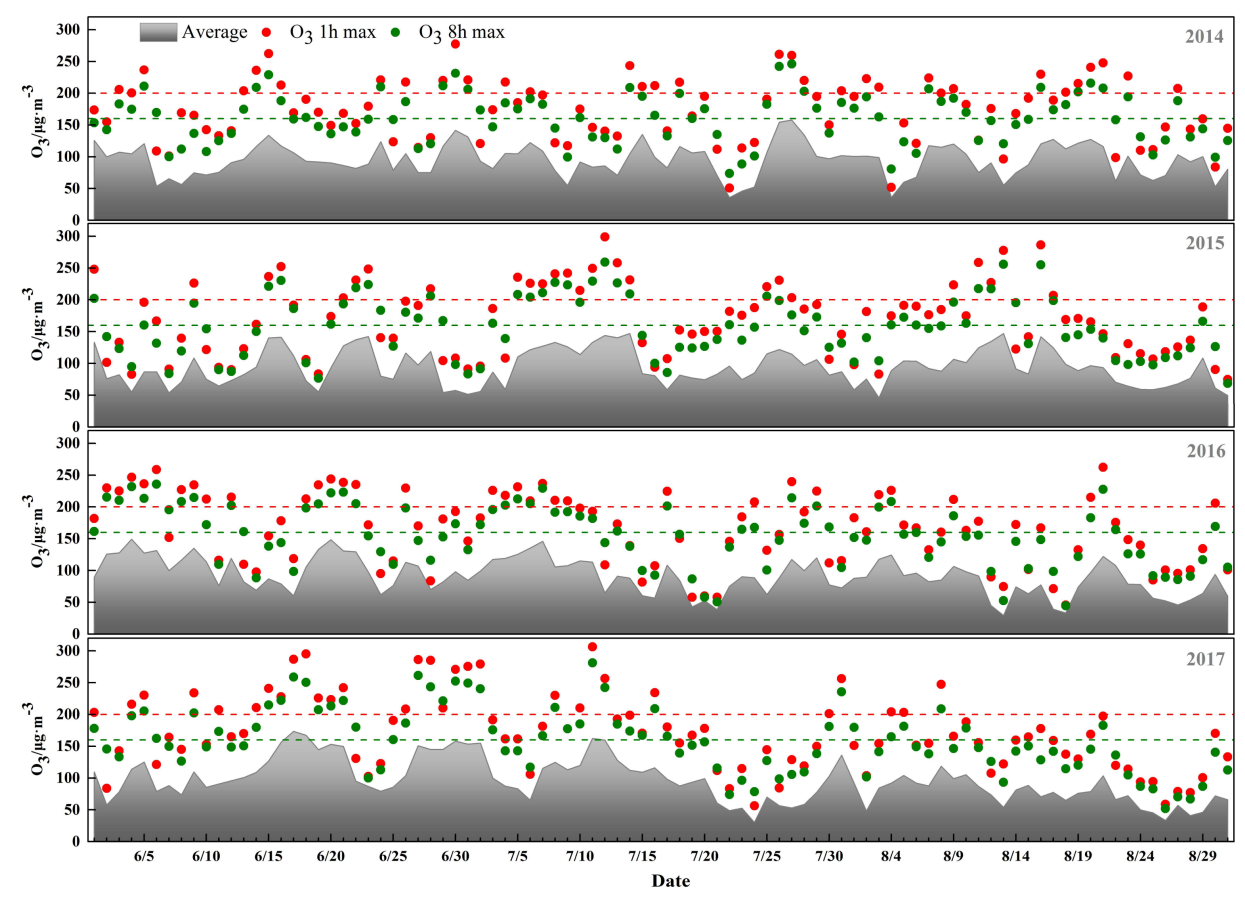

Figure 2. The daily mean ozone concentration and the daily maximum 1-h and 8-h ozone concentrations in different years. 
We also compared meteorological parameters for the periods both when ground-level ozone did and did not exceed the NAAQS threshold, as shown in Table 3. The air temperature was higher during the periods when ground-level ozone exceeded the NAAQS threshold than when ground-level ozone did not exceed the NAAQS threshold. Conversely, relative humidity, wind speed, and precipitation during periods when ground-level ozone exceeded the NAAQS threshold were lower than when ground-level ozone did not exceed the NAAQS threshold. We could not further analyze the mechanism of ground-level ozone formation due to the lack of monitoring of ground-level ozone precursors and other meteorological parameters. To study the impacts of temperature, relative humidity, and wind speed on ozone levels, a multiple regression model between ground-level ozone and meteorological factors was established based on the 2016 data. The model was expressed as ozone $=6.68 \times T-$ $0.79 \times R H+6.74 \times W S-3.17$ with a relatively higher determinant coefficient $\left(R^{2}=0.55, p<0.05\right)$. Additionally, meteorological data for 2017 were used to simulate ground-level ozone concentration to verify the predictability of the model, as shown in Figure 3. We found that the simulated results and the observed ground-level ozone concentration agreed well with each other, with a few differences.

Table 3. Comparison of meteorological parameters during different periods.

\begin{tabular}{lcccc}
\hline & Air Temperature $\left({ }^{\circ} \mathrm{C}\right)$ & Relative Humidity (\%) & Wind Speed (m/s) & $\begin{array}{c}\text { Precipitation } \\
(\mathbf{m m})\end{array}$ \\
\hline $\begin{array}{l}\text { Ozone does not exceed the National } \\
\text { Ambient Air Quality Standards } \\
\text { (NAAQS) threshold }\end{array}$ & 24.82 & 73.85 & 1.81 & 0.32 \\
\hline Ozone exceed the NAAQS threshold & 26.87 & 64.10 & 1.63 & 0.11 \\
\hline
\end{tabular}

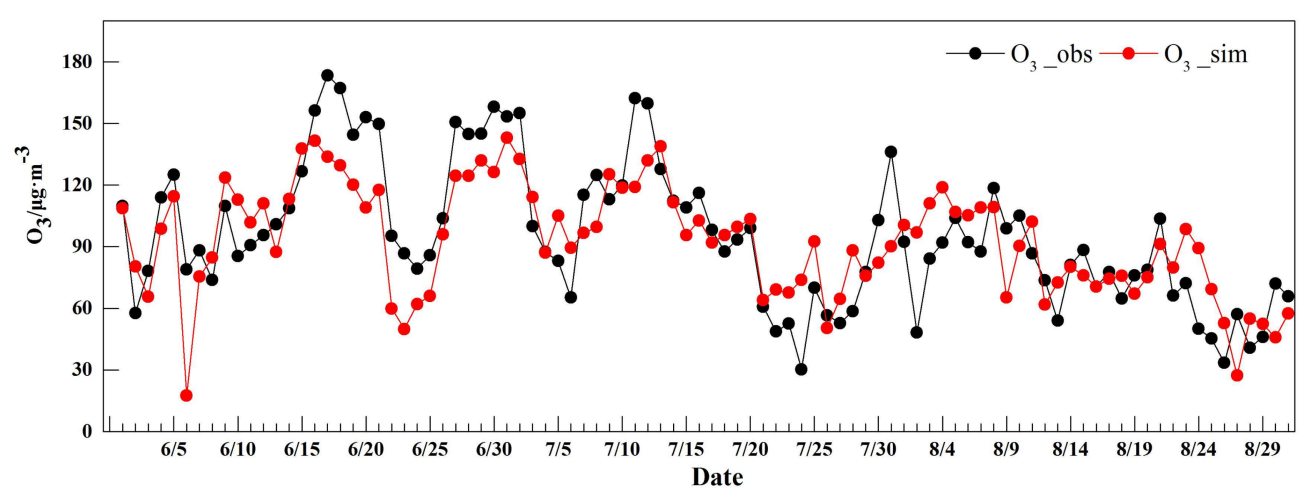

Figure 3. Daily variations in observed and simulated ground-level ozone concentrations.

\subsection{Variations in Ground-Level Ozone Concentration at Four Types of Sites}

As shown in Figure 4, the mean summer ozone concentrations at suburban sites in Beijing in 2014, 2015, 2016, and 2017 were 100.6, 97.7, 96.7, and $104.1 \mu \mathrm{g} / \mathrm{m}^{3}$, respectively, which were higher than those in urban sites. We also found that mean ozone concentrations at the traffic monitoring sites in 2014, 2015, 2016, and 2017 were 69.8, 70.6, 73.5, and $82.7 \mu \mathrm{g} / \mathrm{m}^{3}$, respectively, which were lower than the other three types of sites.

The diurnal variations in ground-level ozone concentration at the four types of monitoring sites are depicted in Figure 5. Overall, although the ground-level ozone concentration varied each year, the basic pattern of the curve showed that the diurnal variation in ground-level ozone at traffic monitoring sites was lower than the other three site types. The four types of monitoring site displayed similar diurnal variation, with ground-level ozone concentrations being lowest in the morning at around 7:00 a.m.-about a half hour after sunrise. The traffic monitoring stations had the lowest values in the morning, at less than $30 \mu \mathrm{g} / \mathrm{m}^{3}$, and the other three sites' lowest ground-level ozone concentrations values were $30-50 \mu \mathrm{g} / \mathrm{m}^{3}$. Ground-level ozone concentrations increased rapidly from 7:00 a.m. until around 3:00-4:00 p.m. for all four sites, when they reached their peak. Except 
for 2017, the highest ground-level ozone concentrations were around $160-180 \mu \mathrm{g} / \mathrm{m}^{3}$ for urban, suburban, and background sites, and the maximum recorded values for the traffic monitoring sites were around $120-140 \mu \mathrm{g} / \mathrm{m}^{3}$. Thereafter, ground-level ozone concentration decreased steadily until the next morning. After midnight, the ground-level ozone remained low and entered a relatively stable phase.
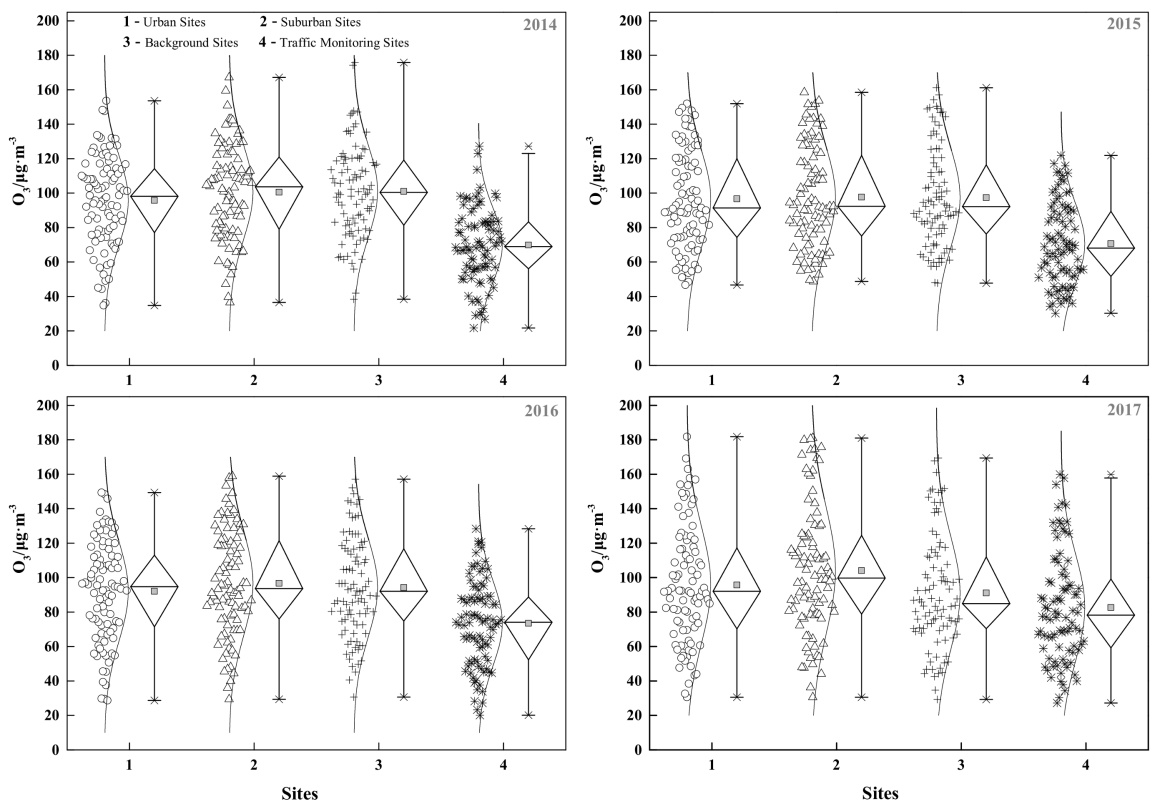

Figure 4. Ground-level ozone concentrations at four types of monitoring sites for different years.
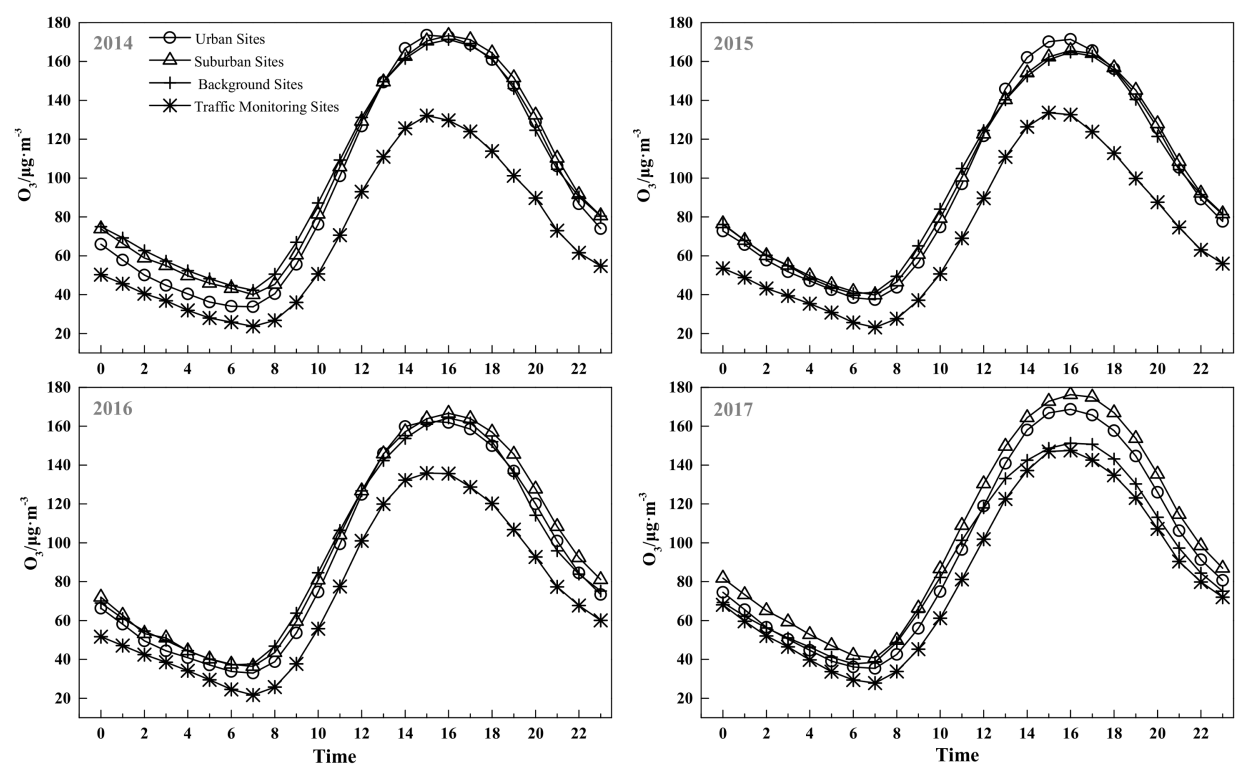

Figure 5. Diurnal variations of ground-level ozone concentrations at four types of monitoring sites in different years.

\subsection{Spatial Distribution of Ground-Level Ozone Concentration}

We further analyzed the mean ozone concentration in each region of Beijing for different years, as shown in Table 4. We found that northeast Beijing had the highest ground-level ozone concentration of the five regions from 2014 to 2017, followed by the northwest and southeast regions. Moreover, 
Beijing's center had lower ground-level ozone concentrations than the rest of the regions for 2014, 2015, and 2017.

Table 4. Ozone mean concentration in each region of Beijing in different years.

\begin{tabular}{ccccc}
\hline \multirow{2}{*}{ Region } & \multicolumn{4}{c}{$\mathbf{O}_{\mathbf{3}}\left(\boldsymbol{\mu} \mathbf{g} / \mathbf{m}^{\mathbf{3}}\right)$} \\
\cline { 2 - 5 } & $\mathbf{2 0 1 4}$ & $\mathbf{2 0 1 5}$ & $\mathbf{2 0 1 6}$ & $\mathbf{2 0 1 7}$ \\
\hline Center & $88.2 \pm 16.6$ & $88.8 \pm 7.4$ & $86.6 \pm 14.9$ & $91.9 \pm 10.4$ \\
Northwest & $105.5 \pm 9.8$ & $99.8 \pm 4.0$ & $97.5 \pm 8.0$ & $98.9 \pm 19.7$ \\
Northeast & $110.7 \pm 7.9$ & $100.5 \pm 10.6$ & $101.9 \pm 10.6$ & $107.0 \pm 11.3$ \\
Southwest & $90.1 \pm 12.7$ & $89.0 \pm 17.0$ & $81.1 \pm 8.8$ & $92.0 \pm 10.0$ \\
Southeast & $91.3 \pm 7.3$ & $97.5 \pm 4.5$ & $95.6 \pm 4.3$ & $96.0 \pm 4.8$ \\
\hline
\end{tabular}

Based on inverse distance weighted interpolation and the ground-level ozone concentration data from 35 air monitoring sites, the spatial distribution of the mean ozone concentration in Beijing during the summer from 2014 to 2017 is shown in Figure 6. The RMSEs of the ground-level ozone maps in 2014, 2015, 2016, and 2017 were 7.89 (about 8.79\%), 8.67 (about 10.21\%), 10.03 (about 11.11\%), and $7.43 \mu \mathrm{g} / \mathrm{m}^{3}$ (about $9.48 \%$ ). Overall, ground-level ozone concentration showed a pronounced decreasing gradient from the north to the south.
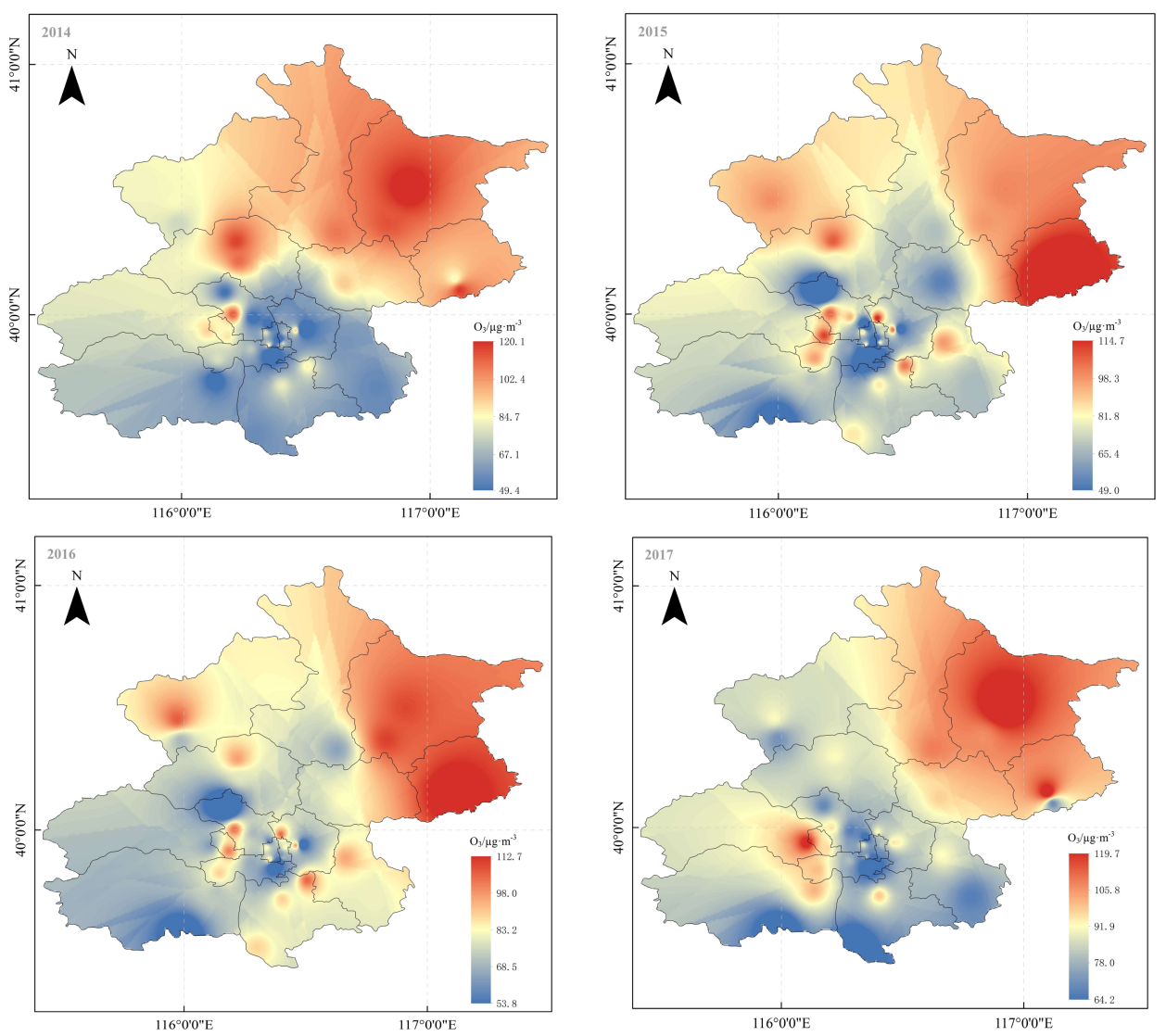

Figure 6. Spatial distribution of ground-level ozone concentration in Beijing in different years.

\subsection{Population Exposure to Ground-Level Ozone}

Figure 7 shows the proportions of the population exposed to ground-level ozone concentrations exceeding the NAAQS of China in the summer in Beijing. Overall, about 10.84 million people $(50.38 \%)$ in Beijing during the summer of 2014 were exposed to ground-level ozone concentrations 
exceeding the NAAQS of China, which was higher than in other years. This was due to the ground-level ozone concentration in densely populated areas, like Changping District and Haidian District, which frequently exceeded the current NAAQS threshold in 2014. In 2015, the number of people exposed to ground-level ozone concentrations exceeding the current NAAQS threshold was about 9.73 million, accounting for $44.85 \%$ of the population, which was the lowest out of the three years. A total of approximately 10.54 million, or $48.49 \%$, of the total Beijing population was exposed to ground-level ozone concentrations exceeding the NAAQS of China in 2016.

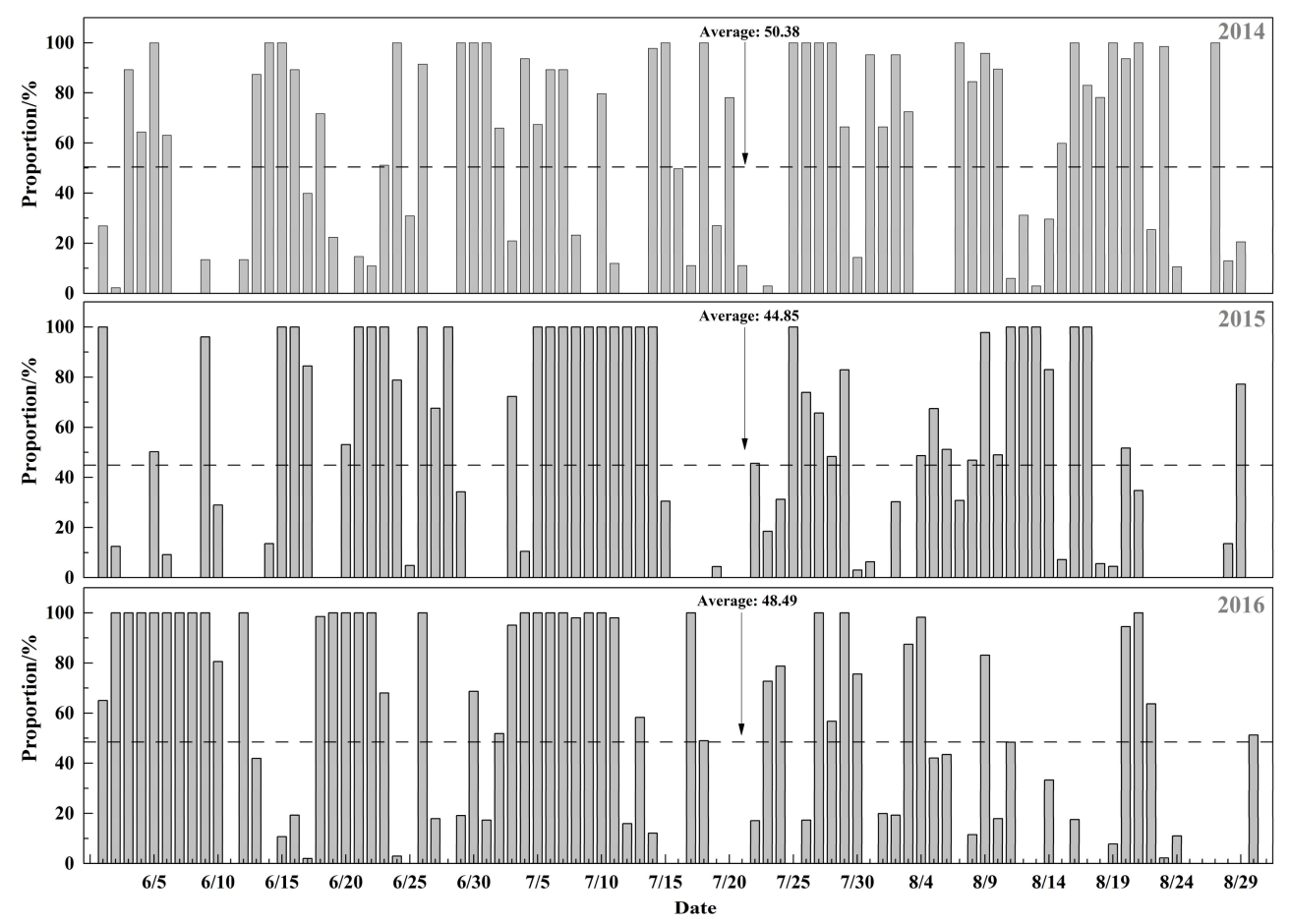

Figure 7. The proportion of the population exposed to ground-level ozone concentrations exceeding the National Ambient Air Quality Standards (NAAQS) of China. The daily 8-h maximum ozone $\left(\mathrm{O}_{3}\right)$ concentration was $160 \mu \mathrm{g} / \mathrm{m}^{3}$ during the summer in Beijing.

\section{Discussion}

Rapid economic growth and urbanization in China has led to increased air pollution, especially in economically developed regions. The Chinese government has formulated and implemented many air pollution control policies and regulations to improve air quality. According to the annual national environmental situation bulletin, ground-level ozone has replaced $\mathrm{PM}_{2.5}$ as the main pollutant in Beijing, as of 2013. Thus, ground-level ozone pollution has become one of the top environmental issues due to its effects on ecosystems, human health and materials. Based on the hourly ground-level ozone concentration data for all 35 ambient air quality monitoring sites in Beijing during the summers of 2014 to 2017, the temporal and spatial distribution of, and population exposure to, ground-level ozone were analyzed in this paper.

In this study, we found that mean ozone concentrations at suburban sites were higher than those in urban sites. This phenomenon was essentially consistent with a few previous studies [54,55]. Ozone formation is driven by two main components of directly emitted precursors: $\mathrm{NO}_{\mathrm{X}}$ and VOCs. However, ozone generation is a complex nonlinear relationship with its precursors. A few studies showed that local ozone production depends on the ratio of VOC to $\mathrm{NO}_{\mathbf{X}}[56,57]$, which can explain why high ground-level ozone concentrations usually occur in the suburban areas [7]. In this case, ground-level ozone increased with increasing VOC, but decreased with increasing $\mathrm{NO}_{\mathrm{X}}$. In general, 
low $\mathrm{VOC}$ to $\mathrm{NO}_{\mathrm{X}}$ ratios are observed in urban areas due to the high concentration of $\mathrm{NO}_{\mathrm{X}}$, and $\mathrm{NO}_{\mathrm{X}}$ tends to inhibit ozone formation [6]. Therefore, higher ground-level ozone concentrations are found in suburban compared with urban areas, because ozone levels are higher downwind of ozone precursor sources at distances of hundreds or even thousands of kilometers [2,6,58]. Higher biogenic VOC emissions, low ozone titration by NO, and ozone and / or precursor transport from urban areas are factors that explain the higher ozone pollution at suburban sites $[59,60]$. In addition, biogenic volatile organic compounds emitted by vegetation and anthropogenic VOCs emitted by human activities are both commonly present in suburban sites [61], which can also contribute to the formation of ground-level ozone. In addition, mean ozone concentrations at the traffic monitoring sites were lower than the other three types of sites. This phenomenon can be explained by the high number of motor vehicles at the traffic monitoring sites, which produce a large amount of exhaust, leading to the increase in the emission of ozone precursors $\left(\mathrm{NO}\right.$ and $\mathrm{NO}_{2}$ ). Although the high $\mathrm{NO}_{2}$ concentrations at the traffic monitoring sites are conducive to the formation of ground-level ozone through photolysis, ozone can react with $\mathrm{NO}$ to convert it into $\mathrm{NO}_{2}$ and $\mathrm{O}_{2}$. In addition, the $\mathrm{NO}_{2}$ loss processes in polluted regions are the final loss processes for ground-level ozone [62].

Increased solar radiation and temperature and decreased relative humidity can increase the rates of photochemical reactions that enhance the ozone level in the atmosphere, which explains why the ground-level ozone had an obvious diurnal variation pattern. During the daytime, with an increase in solar radiation and temperature, the atmospheric photochemical processes of ozone production also increase, which leads to the constant conversion of precursors (VOCs, $\mathrm{NO}_{x}$, and others) to ground-level ozone [7]. Additionally, ozone at high altitudes is transported to the ground due to atmospheric vertical diffusion during this period $[20,63,64]$. The ground-level ozone remained low at night because of the lack of $\mathrm{NO}_{2}$ photolysis reactions and photooxidation of $\mathrm{CO}, \mathrm{VOC}_{\mathrm{S}}$, and other ozone precursors. This coincides with the rapid destruction of $\mathrm{O}_{3}$ by $\mathrm{NO}$ with no replenishment from the stratosphere occurring by night due to the stable air temperature profile $[6,65]$. This diurnal pattern is similar to those found in several cities $[31,38,66]$.

Spatially, ground-level ozone concentrations in Northern Beijing were higher than those in Southern Beijing. Previous studies found that the $\mathrm{PM}_{2.5}$ concentration in Northern Beijing was lower than in Southern Beijing $[67,68]$, suggesting that the surface solar radiation was weaker in Southern Beijing than in Northern Beijing, which was conducive to the formation of ground-level ozone through photochemical reactions. Furthermore, Northern Beijing is surrounded by the mountains with a considerable amount of green vegetation. VOCs emitted from this green vegetation may also contribute to regional ozone formation in the Northern part of Beijing [54,61]. Conversely, Southern Beijing has more motor vehicles, resulting in increased vehicle exhaust, leading to increased NOx emission and thus strongly inhibiting ground-level ozone formation [47].

A large number of studies reported population exposure to $\mathrm{PM}_{2.5}$ in Beijing $[67,69-71]$, and these studies were based on satellite data and model simulation results, which affects the reliability of the conclusions. However, a few studies attempted to study population exposure to ground-level ozone in Beijing. Consequently, to investigate the risk caused by summertime ground-level ozone for the entire Beijing population, the proportion of the population exposed to ground-level ozone concentrations exceeding the current NAAQS threshold was calculated by using the daily maximum 8-h ground-level ozone concentration of $160 \mu \mathrm{g} / \mathrm{m}^{3}$ and population survey data from all of Beijing's 16 districts. Our research showed a higher risk of ground-level ozone exposure in Beijing. Taken together, this study reveals the significantly high health risk from ground-level ozone pollution and indicates a future direction for air pollution control. Given these results, the Chinese government must formulate environmental policies to reduce ground-level ozone pollution and the population's exposure and achieve sustainable development. In future epidemiologic studies, the relationship between ground-level ozone and mortality, such as from chronic cardiovascular and respiratory diseases, should be established. 


\section{Conclusions}

During the summer in Beijing from 2014 to 2017, more than 40 days had a ground-level ozone concentration exceeding the current NAAQS threshold. We established a multiple regression model between the meteorological parameters and ground-level ozone concentration to study the impact of air temperature, relative humidity, and wind speed on ozone levels. The test results indicated that the model could be used to simulate ground-level ozone concentration based on observational meteorological data. Of the different types of monitoring sites, the traffic monitoring sites showed the lowest ground-level ozone concentrations due to the fast titration of ozone by NO. The mean ozone concentrations at the suburban sites were higher than those at the urban sites, which could be explained by the ratio of VOC to $\mathrm{NO}_{\mathbf{X}}$. In addition, the VOCs emitted from vegetation and human activities could also contribute to the formation of ground-level ozone. The diurnal variation in ground-level ozone concentration displayed a single-peak curve, with the minimum and maximum mean concentrations occurring at around 7:00 a.m. and 3:00-4:00 p.m., respectively. Overall, the ground-level ozone concentration displayed a pronounced spatial gradient, increasing from the south to the north of the region, due to the differences in vehicle exhaust, emitted VOCs, and $\mathrm{PM}_{2.5}$ concentration between Northern and Southern Beijing. A major challenge for assessing the health impacts of ground-level ozone pollution is the lack of monitoring data in China. Based on ground-level ozone concentrations and the population data of 16 districts in Beijing, we found that the number of individuals in the population exposed to ground-level ozone concentrations exceeding the NAAQS of China in 2014, 2015, and 2016 were 10.84 million, 9.73 million, and 10.54 million, respectively, accounting for approximately $50.38 \%, 44.85 \%$, and $48.49 \%$ of the Beijing population.

High levels of ground-level ozone pollution are posing a serious threat to human health, according to our research. We propose the following recommendations to effectively reduce ground-level ozone pollution and improve the air quality in Beijing:

1. Strict laws are required to control the emissions of ozone precursors ( $\mathrm{NO}_{\mathrm{X}}$ and VOCs), which are mainly from motor vehicle exhaust. In the short term, replacing old cars with newer vehicles, or eliminating old cars with subsidies, are useful policy strategies. In the long term, developing public transportation to help reduce the use of private cars in major and populous cities is also required.

2. To avoid an increase in ground-level ozone concentrations, measures for controlling VOC sources (like gasoline stations and paint use) should be stricter than those for $\mathrm{NO}_{\mathrm{X}}$ sources, because most areas in Beijing are VOC-dominated ozone pollution areas, where the ozone concentration is determined by the concentration of VOC in the atmosphere. Thus, the relevant research community and government agencies need to pay more attention to research on the measurement of VOCs and their effects on ozone production in the atmosphere.

3. As previous studies have shown, ozone pollution in Beijing is considerably affected by the transport of ozone and its precursors from other provinces in Northern China. Regional cooperation and joint defense and control are future directions for the control of ozone pollution.

4. Research on the impacts of ground-level ozone pollution on human health and vegetation is limited compared to that on atmospheric processes. We recommend that more research be conducted on the impacts of ground-level ozone and consideration be given to further reducing the guideline values for Class II regions.

Acknowledgments: This work was financially supported by the National Natural Science Fund (41475108), Research Innovation Program for College Graduates of Jiangsu Province (KYCX17_0878), and the Visiting Fellowship from China Scholarship Council (No. 201708320313).

Author Contributions: Hui Zhao and Youfei Zheng conceived and designed the experiments as well as writing the paper; Hui Zhao and Ting Li analyzed the data; Ting Li, Li Wei and Qing Guan helped perform the statistical analysis.

Conflicts of Interest: The authors declare no conflict of interest. 


\section{References}

1. Cristofanelli, P.; Carlo, P.D.; Altorio, A.D.; Salisburgo, C.D.; Tuccella, P.; Biancofiore, F.; Stocchi, P.; Verza, G.P.; Landi, T.C.; Marinoni, A.; et al. Analysis of summer ozone observations at a high mountain site in central Italy (campo imperatore, 2388 m a.s.1.). Pure Appl. Geophys. 2013, 170, 1985-1999. [CrossRef]

2. Sicard, P.; Marco, A.D.; Troussier, F.; Renou, C.; Vas, N.; Paoletti, E. Decrease in surface ozone concentrations at Mediterranean remote sites and increase in the cities. Atmos. Environ. 2013, 79, 705-715. [CrossRef]

3. Derwent, R.G.; Utembe, S.R.; Jenkin, M.E.; Shallcross, D.E. Tropospheric ozone production regions and the intercontinental origins of surface ozone over Europe. Atmos. Environ. 2015, 112, 216-224. [CrossRef]

4. Vestreng, V.; Ntziachristos, L.; Semb, A.; Reis, S.; Isaksen, I.S.A.; Tarrasón, L. Evolution of NOx emissions in Europe with focus on road transport control measures. Atmos. Chem. Phys. 2009, 8, 1503-1520. [CrossRef]

5. Xing, J.; Mathur, R.; Pleim, J.; Hogrefe, C.; Gan, C.M.; Wong, D.C.; Wei, C.; Gilliam, R.; Pouliot, G. Observations and modeling of air quality trends over 1990-2010 across the Northern Hemisphere: China, the United States and Europe. Atmos. Chem. Phys. 2015, 14, 2723-2747. [CrossRef]

6. Sicard, P.; Serra, R.; Rossello, P. Spatiotemporal trends in ground-level ozone concentrations and metrics in France over the time period 1999-2012. Environ. Res. 2016, 149, 122-144. [CrossRef] [PubMed]

7. Monks, P.S.; Archibald, A.T.; Colette, A.; Cooper, O.; Coyle, M.; Derwent, R.; Fowler, D.; Granier, C.; Law, K.S.; Mills, G.E.; et al. Tropospheric ozone and its precursors from the urban to the global scale from air quality to short-lived climate forcer. Atmos. Chem. Phys. 2015, 14, 32709-32933. [CrossRef]

8. Karnosky, D.F.; Skelly, J.M.; Percy, K.E.; Chappelka, A.H. Perspectives regarding 50 years of research on effects of tropospheric ozone air pollution on US forests. Environ. Pollut. 2007, 147, 489-506. [CrossRef] [PubMed]

9. Screpanti, A.; Marco, A.D. Corrosion on cultural heritage buildings in Italy: A role for ozone? Environ. Pollut. 2009, 157, 1513-1520. [CrossRef] [PubMed]

10. Mills, G.; Hayes, F.; Simpson, D.; Emberson, L.; Norris, D.; Harmens, H.; Buker, P. Evidence of widespread effects of ozone on crops and (semi-) natural vegetation in Europe (1990-2006) in relation to AOT40- and flux-based risk maps. Glob. Chang. Biol. 2011, 17, 592-613. [CrossRef]

11. Paoletti, E. Impact of ozone on Mediterranean forests: A review. Environ. Pollut. 2006, 144, 463-474. [CrossRef] [PubMed]

12. Sicard, P.; Dalstein-Richier, L. Health and vitality assessment of two common pine species in the context of climate change in southern Europe. Environ. Res. 2015, 137, 235-245. [CrossRef] [PubMed]

13. Calatayud, V.; Diéguez, J.J.; Sicard, P.; Schaub, M.; Marco, A.D. Testing approaches for calculating stomatal ozone fluxes from passive samplers. Sci. Total Environ. 2016, 572, 56-67. [CrossRef] [PubMed]

14. Anav, A.; Marco, A.D.; Proietti, C.; Alessandri, A.; Dell'Aquila, A.; Cionni, I.; Friedlingstein, P.; Khvorostyanov, D.; Menut, L.; Paoletti, E.; et al. Comparing concentration-based (AOT40) and stomatal uptake (PODY) metrics for ozone risk assessment to European forests. Glob. Chang. Biol. 2016, 22, 1608-1627. [CrossRef] [PubMed]

15. Ochoa-Hueso, R.; Munzi, S.; Alonso, R.; Arróniz-Crespo, M.; Avila, A.; Bermejo, V.; Bobbink, R.; Branquinho, C.; Concostrina-Zubiri, L.; Cruz, C.; et al. Ecological impacts of atmospheric pollution and interactions with climate change in terrestrial ecosystems of the Mediterranean Basin: Current research and future directions. Environ. Pollut. 2017, 227, 194-206. [CrossRef] [PubMed]

16. Sicard, P.; Anav, A.; Marco, A.D.; Paoletti, E. Projected global tropospheric ozone impacts on vegetation under different emission and climate scenarios. Atmos. Chem. Phys. 2017, 17, 12177-12196. [CrossRef]

17. Javanmardi, P.; Morovati, P.; Farhadi, M.; Geravandi, S.; Khaniabadi, Y.O.; Angali, K.A.; Taiwo, A.; Sicard, P.; Goudarzi, G.; Valipour, A.; et al. Monitoring the impact of ambient ozone on human health using time series analysis and air quality model approaches. Fresenius Environ. Bull. 2018, 27, 533-544.

18. Paoletti, E.; Sicard, P. Preface to the IUFRO RG7.01 special section "Global Challenges of Air Pollution and Climate Change to Forests". Environ. Pollut. 2016, 213, 975-976. [CrossRef] [PubMed]

19. Proietti, C.; Anav, A.; Marco, A.D.; Sicard, P.; Vitale, M. A multi-sites analysis on the ozone effects on Cross Primary Production of European forests. Sci. Total Environ. 2016, 556, 1-11. [CrossRef] [PubMed]

20. Vingarzan, R. A review of surface ozone background levels and trends. Atmos. Environ. 2004, 38, 3431-3442. [CrossRef] 
21. Derwent, R.G.; Simmonds, P.G.; Manning, A.J.; Spain, T.G. Trends over a 20-year period from 1987 to 2007 in surface ozone at the atmospheric research station, Mace Head, Ireland. Atmos. Environ. 2007, 41, 9091-9098. [CrossRef]

22. Jaffe, D.; Ray, J. Increase in surface ozone at rural sites in the western US. Atmos. Environ. 2007, 41, 5452-5463. [CrossRef]

23. Fiala, J.; Cernikovsky, L.; Leeuw, F.D.; Kurfuerst, P. Air Pollution by Ozone in Europe in Summer 2003. Overview of Exceedances of EC Ozone Threshold Values during the Summer Season April-August 2003 and Comparisons with Previous Years; European Environment Agency: Copenhagen, Denmark, 2003.

24. Wang, W.N.; Cheng, T.H.; Gu, X.F.; Chen, H.; Guo, H.; Wang, Y.; Bao, F.W.; Shi, S.Y.; Xu, B.R.; Zuo, X.; et al. Assessing spatial and temporal patterns of observed ground-level ozone in China. Sci. Rep. 2017, 7, 3651. [CrossRef] [PubMed]

25. Lelieveld, J.; Berresheim, H.; Borrmann, S.; Crutzen, P.J.; Dentener, F.J.; Fischer, H.; Feichter, J.; Flatau, P.J.; Heland, J.; Holzinger, R.; et al. Global air pollution crossroads over the Mediterranean. Science 2002, 298, 794-799. [CrossRef] [PubMed]

26. Hu, J.L.; Wang, Y.G.; Ying, Q.; Zhang, H.L. Spatial and temporal variability of $\mathrm{PM}_{2.5}$ and $\mathrm{PM}_{10}$ over the North China Plain and the Yangtze River Delta, China. Atmos. Environ. 2014, 95, 598-609.

27. Cai, S.Y.; Wang, Y.J.; Zhao, B.; Wang, S.X.; Chang, X.; Hao, J.M. The impact of the "Air Pollution Prevention and Control Action Plan" on $\mathrm{PM}_{2.5}$ concentrations in Jing-Jin-Ji region during 2012-2020. Sci. Total Environ. 2017, 580, 197-209. [CrossRef] [PubMed]

28. Liu, H.; Wang, X.M.; Pang, J.M.; He, K.B. Feasibility and difficulties of China's new air quality standard compliance: PRD case of $\mathrm{PM}_{2.5}$ and ozone from 2010 to 2025. Atmos. Chem. Phys. 2013, 13, 12013-12027. [CrossRef]

29. Liu, H.; Liu, S.; Xue, B.R.; Lv, Z.F.; Meng, Z.H.; Yang, X.F.; Xue, T.; Yu, Q.; He, K.B. Ground-level ozone pollution and its health impacts in China. Atmos. Environ. 2018, 173, 223-230. [CrossRef]

30. Trieu, T.T.N.; Goto, D.; Yashiro, H.; Murata, R.; Sudo, K.; Tomita, H.; Satoh, M.; Nakajima, T. Evaluation of summertime surface ozone in Kanto area of Japan using a semi-regional model and observation. Atmos. Environ. 2017, 153, 163-181. [CrossRef]

31. Latif, M.T.; Huey, L.S.; Juneng, L. Variations of surface ozone concentration across the Klang Valley, Malaysia. Atmos. Environ. 2012, 61, 434-445. [CrossRef]

32. Pu, X.; Wang, T.J.; Huang, X.; Melas, D.; Zanis, P.; Papanastasiou, D.K.; Poupkou, A. Enhanced surface ozone during the heat wave of 2013 in Yangtze River Delta region, China. Sci. Total Environ. 2017, 603-604, 807-816. [CrossRef] [PubMed]

33. Lin, C.Y.C.; Jacob, D.J.; Fiore, A.M. Trends in exceedances of the ozone air quality standard in the Continental United States, 1980-1998. Atmos. Environ. 2001, 35, 3217-3228. [CrossRef]

34. Zhang, J.; Rao, S.T.; Daggupaty, S.M. Meteorological processes and ozone exceedances in the Northeastern United States during the 12-16 July 1995 episode. J. Appl. Meteorol. 1988, 37, 776-789. [CrossRef]

35. Tarasova, O.A.; Karpetchko, A.Y. Accounting for local meteorological effects in the ozone time-series of Lovozero (Kola Peninsula). Atmos. Chem. Phys. 2003, 3, 941-949. [CrossRef]

36. Song, C.B.; Wu, L.; Xie, Y.C.; He, J.J.; Chen, X.; Wang, T.; Lin, Y.C.; Jin, T.S.; Wang, A.X.; Liu, Y.; et al. Air pollution in China: Status and spatiotemporal variations. Environ. Pollut. 2017, 227, 334-347. [CrossRef] [PubMed]

37. WHO (World Health Organization). Review of Evidence on Health Aspects of Air Pollution e REVIHAAP Project Technical Report; WHO Regional Office for Europe: Copenhagen, Denmark, 2013.

38. Wang, T.; Xue, L.; Brimblecombe, P.; Lam, Y.F.; Li, L.; Zhang, L. Ozone pollution in China: A review of concentrations, meteorological influences, chemical precursors, and effects. Sci. Total Environ. 2017, 575, 1582-1596. [CrossRef] [PubMed]

39. Sicard, P.; Talbot, C.; Lesne, O.; Mangin, A.; Alexandre, N.; Collomp, R. The Aggregate Risk Index: An intuitive tool providing the health risks of air pollution to health care community and public. Atmos. Environ. 2012, 46, 11-16. [CrossRef]

40. Bell, M.L.; Goldberg, R.; Hogrefe, C.; Kinney, P.L.; Knowlton, K.; Lynn, B.; Rosenthal, J.; Rosenzweig, C.; Patz, J.A. Climate change, ambient ozone, and health in 50 US cities. Clim. Chang. 2007, 82, 61-76. [CrossRef] 
41. Goodman, J.E.; Prueitt, R.L.; Sax, S.N.; Pizzurro, D.M.; Lynch, H.N.; Zu, K. Ozone exposure and systemic biomarkers: Evaluation of evidence for adverse cardiovascular health impacts. Crit. Rev. Toxicol. 2015, 45, 412-452. [CrossRef] [PubMed]

42. Wang, Z.S.; Li, Y.T.; Chen, T.; Zhang, D.W.; Sun, F.; Wei, Q.; Dong, X.; Sun, R.W.; Huan, N.; Pan, L.B. Ground-level ozone in urban Beijing over a 1-year period: Temporal variations and relationship to atmospheric oxidation. Atmos. Res. 2015, 164-165, 110-117. [CrossRef]

43. He, J.J.; Gong, S.L.; Yu, Y.; Yu, L.J.; Wu, L.; Mao, H.J.; Song, C.B.; Zhao, S.P.; Liu, H.L.; Li, X.Y.; et al. Air pollution characteristics and their relation to meteorological conditions during 2014-2015 in major Chinese cities. Environ. Pollut. 2017, 223, 484-496. [CrossRef] [PubMed]

44. Wang, T.; Ding, A.J.; Gao, J.; Wu, W.S. Strong ozone production in urban plumes from Beijing, China. Geophy. Res. Lett. 2006, 33, 320-337. [CrossRef]

45. Tang, G.; Li, X.; Wang, Y.; Xin, J.; Ren, X. Surface ozone trend details and interpretations in Beijing, 2001-2006. Atmos. Chem. Phys. 2009, 9, 8813-8823. [CrossRef]

46. Wang, T.; Nie, W.; Gao, J.; Xue, L.K.; Gao, X.M.; Wang, X.F.; Qiu, J.; Poon, C.N.; Meinardi, S.; Blake, D.; et al. Air quality during the 2008 Beijing Olympics: Secondary pollutants and regional impact. Atmos. Chem. Phys. 2010, 10, 7603-7615. [CrossRef]

47. Tang, X.; Wang, Z.F.; Zhu, J.; Gbaguidi, A.E.; Wu, Q.Z.; Li, J.; Zhu, T. Sensitivity of ozone to precursor emissions in urban Beijing with a Monte Carlo scheme. Atmos. Environ. 2010, 44, 3833-3842. [CrossRef]

48. Wang, Z.S.; Li, Y.T.; Chen, T.; Li, L.J.; Liu, B.X.; Zhang, D.W.; Sun, F.; Wei, Q.; Jiang, L.; Pan, L.B. Changes in atmospheric composition during the 2014 APEC conference in Beijing. J. Geophys. Res. Atmos. 2015, 120, 695-707. [CrossRef]

49. Li, R.K.; Li, Z.P.; Gao, W.J.; Ding, W.J.; Xu, Q.; Song, X.F. Diurnal, seasonal, and spatial variation of $\mathrm{PM}_{2.5}$ in Beijing. Sci. Bull. 2015, 60, 387-395. [CrossRef]

50. Michanowicz, D.R.; Shmool, J.L.C.; Tunno, B.J.; Tripathy, S.; Gillooly, S.; Kinnee, E.; Clougherty, J.E. A hybrid land use regression/AERMOD model for predicting intra-urban variation in $\mathrm{PM}_{2.5}$. Atmos. Environ. 2016, 131, 307-315. [CrossRef]

51. Lavi, A.; Potchter, O.; Omer, I.; Fireman, E. Mapping air pollution by biological monitoring in the metropolitan Tel Aviv area. Int. J. Environ. Heal. Res. 2015, 26, 346-360. [CrossRef] [PubMed]

52. Allshouse, W.B.; Adgate, J.L.; Blair, B.D.; McKenzie, L.M. A spatiotemporal industrial activity model for estimating the intensity of oil and gas operations in Colorado. Environ. Sci. Technol. 2017, 51, 10243-10250. [CrossRef] [PubMed]

53. Li, T.X.; Zhou, X.K.; Ikhumhen, H.O.; Difei, A. Research on the optimization of air quality monitoring station layout based on spatial grid statistical analysis method. Environ. Technol. 2017. [CrossRef] [PubMed]

54. Chen, N.L.; Li, Y.T.; Zhang, D.W.; Chen, T.; Sun, F.; Chen, C.; Meng, F. Characteristics of ground ozone concentration over Beijing from 2004 to 2015: Trends, transport, and effects of reductions. Atmos. Chem. Phys. 2016. [CrossRef]

55. Guo, H.; Wang, Y.G.; Zhang, H.L. Characterization of criteria air pollutants in Beijing during 2014-2015. Environ. Res. 2017, 154, 334-344. [CrossRef] [PubMed]

56. Kang, D.; Aneja, V.P.; Mathur, R.; Ray, J.D. Observed and modeled VOC chemistry under high $\mathrm{VOC} / \mathrm{NO}_{\mathrm{X}}$ conditions in the Southeast United States national parks. Atmos. Environ. 2004, 38, 4969-4974. [CrossRef]

57. Pusede, S.E.; Cohen, R.C. On the observed response of ozone to NOx and VOC reactivity reductions in San Joaquin Valley California 1995-present. Atmos. Chem. Phys. 2012, 12, 8323-8339. [CrossRef]

58. Guerreiro, C.B.B.; Foltescu, V.; Leeuw, F.D. Air quality status and trends in Europe. Atmos. Environ. 2014, 98, 376-384. [CrossRef]

59. Sicard, P.; Dalstein-Richier, L.; Vas, N. Annual and seasonal trends of ambient ozone concentration and its impact on forest vegetation in Mercantour National Park (South-eastern France) over the 2000-2008 period. Environ. Pollut. 2011, 159, 351-362. [CrossRef] [PubMed]

60. Paoletti, E.; Marco, A.D.; Beddows, D.C.S.; Harrison, R.M.; Manning, W.J. Ozone levels in European and USA cities are increasing more than at rural sites, while peak values are decreasing. Environ. Pollut. 2014, 192, 295-299. [CrossRef] [PubMed]

61. Kang, D.; Aneja, V.P.; Zika, R.G.; Farmer, C.; Ray, J.D. Nonmethane hydrocarbons in the rural southeast United States national parks. J. Geophys. Res. 2001, 106, 3133-3155. [CrossRef] 
62. Lu, K.D.; Zhang, Y.H.; Su, H.; Shao, M.; Zeng, L.M.; Zhong, L.J.; Xiang, Y.R.; Chang, C.C.; Chou, C.K.C.; Wahner, A. Regional ozone pollution and key controlling factors of photochemical ozone production in Pearl River Delta during summer time. Sci. China Chem. 2010, 53, 651-663. [CrossRef]

63. Wang, Y.G.; Ying, Q.; Hu, J.L.; Zhang, H.L. Spatial and temporal variations of six criteria air pollutants in 31 provincial capital cities in China during 2013-2014. Environ. Int. 2014, 73, 413-422. [CrossRef] [PubMed]

64. Cheng, L.J.; Wang, S.; Gong, Z.Y.; Li, H.; Yang, Q.; Wang, Y.Y. Regionalization based on spatial and seasonal variation in ground-level ozone concentrations across China. J. Environ. Sci. 2017. [CrossRef]

65. Reddy, B.S.K.; Reddy, L.S.S.; Cao, J.J.; Kumar, K.R.; Balakrishnaiah, G.; Gopal, K.R.; Reddy, R.R.; Narasimhulu, K.; Lal, S.; Ahammed, Y.N. Simultaneous Measurements of Surface Ozone at Two Sites over the Southern Asia: A Comparative Study. Aerosol. Air Qual. Res. 2011, 11, 895-902. [CrossRef]

66. An, J.L.; Zou, J.N.; Wang, J.X.; Lin, X.; Zhu, B. Differences in ozone photochemical characteristics between the megacity Nanjing and its suburban surroundings, Yangtze River Delta, China. Environ. Sci. Pollut. Res. 2015, 22, 19607-19617. [CrossRef] [PubMed]

67. Xie, Y.Y.; Wang, Y.X.; Zhang, K.; Dong, W.H.; Lv, B.L.; Bai, Y.Q. Daily estimation of ground-level $\mathrm{PM}_{2.5}$ concentrations over Beijing using 3 km resolution MODIS AOD. Environ. Sci. Technol. 2015, 49, 12280-12288. [CrossRef] [PubMed]

68. Wang, Y.L.; Yang, W.; Han, B.; Zhang, W.J.; Chen, M.D.; Bai, Z.P. Gravimetric analysis for PM 2.5 mass concentration based on year-round monitoring at an urban site in Beijing. J. Environ. Sci. 2016, 40, 154-160. [CrossRef] [PubMed]

69. Zhang, A.; Qi, Q.W.; Jiang, L.L.; Zhou, F.; Wang, J.F. Population Exposure to $\mathrm{PM}_{2.5}$ in the Urban Area of Beijing. PLoS ONE 2013. [CrossRef] [PubMed]

70. Feng, X.; Li, Q.; Zhu, Y.J.; Hou, J.X.; Wang, J.H. An estimate of population exposure to automobile source $\mathrm{PM}_{2.5}$ in Beijing using spatiotemporal analysis. In Proceedings of the 2015 IEEE International Geoscience and Remote Sensing Symposium (IGARSS), Milan, Italy, 26-31 July 2015; pp. 3029-3032.

71. Chen, Li.; Shi, M.S.; Gao, S.; Li, S.H.; Mao, J.; Zhang, H.; Sun, Y.L.; Bai, Z.P.; Wang, Z.L. Assessment of population exposure to $\mathrm{PM}_{2.5}$ for mortality in China and its public health benefit based on BenMAP. Environ. Pollut. 2017, 221, 311-317. [CrossRef] [PubMed] 